\title{
Perendaman semen ionomer kaca konvensional dalam kefir terhadap kekerasan permukaan
}

\author{
*Soraya Dian Permata Rezky, **Titien Hary Agustantina, **Devi Rianti \\ "Mahasiswa \\ ${ }^{* *}$ Bagian Dental Material \\ Fakultas Kedokteran Gigi, Universitas Airlangga \\ Surabaya, Indonesia
}

\begin{abstract}
Conventional glass ionomer cement is a restorative material used in dentistry. Kefir is a beverage as a result of milk fermentation milk and kefir seeds. Know the change of surface hardness in conventional glass ionomer cement after soaking in kefir. Nine sample discs $(5 \mathrm{~mm}$ in diameter and $3 \mathrm{~mm}$ thick) were prepared, each disc contained 6 samples. All samples prepared following the manufacturers' instructions then kept for 24 hours at room temperature before soaking in aquades and kefir. Vickers microhardness was used to measure the surface hardness at the top surface of the sample. Data were statistically analyzed using ANOVA and LSD ( $p<0.05)$. This study indicated that soaking of conventional glass ionomer cement in aquades and kefir decreased surface hardness. The conclusion is conventional glass ionomer cement soaked in kefir for a long time (108 hours) decreased in the surface hardness largely. Key words: kefir, glass ionomer cement, surface hardness, soaking time
\end{abstract}

\begin{abstract}
ABSTRAK
Semen ionomer kaca konvensional adalah bahan restorasi yang digunakan dalam bidang kedokteran gigi. Kefir adalah minuman sebagai hasil fermentasi susu dan biji kefir. Tujuan penelitian ini untuk mengetahui perubahan kekerasan permukaan semen ionomer kaca konvensional setelah perendaman dalam kefir. Sembilan sampel disc (diameter $5 \mathrm{~mm}$ dan tebal $3 \mathrm{~mm}$ ) disiapkan untuk masing-masing enam kelompok sampel. Semua sampel dipersiapkan menurut rekomendasi pabrik, disimpan selama 24 jam pada suhu kamar sebelum perendaman dalam dalam akuades dan kefir. Vickers microhardness digunakan untuk mengukur kekerasan permukaan atas dari masingmasing sampel. Data diuji secara statistik ANOVA and LSD $(\mathrm{p}<0,05)$, menunjukkan bahwa perendaman semen ionomer kaca konvensional dalam akuades dan kefir menurunkan kekerasan permukaan. Dapat disimpulkan bahwa semen ionomer kaca konvensional yang telah direndam dalam kefir untuk jangka waktu lama (108 hours) mengurangi kekerasan permukaan secara bermakna.
\end{abstract}

Key words: kefir, semen ionomer kaca, kekerasan permukaan, waktu perendaman

Koresponden: Titien Hary Agustantina, Fakultas Kedokteran Gigi Universitas Airlangga. Jl. Mayjen. Prof. Dr. Moestopo 47 Surabaya 60132, Indonesia. E-mail: titienha@gmail.com

\section{PENDAHULUAN}

Semen ionomer kaca konvensional telah digunakan secara luas di bidang kedokteran gigi sejak diperkenalkan oleh Wilson dan Kent pada tahun 1971. Semen ini terdiri dari bubuk kaca kalsium fluoroaluminosilikat dan larutan asam 
poliakrilat. Bahan ini dikenal dengan nama semen ionomer kaca konvensional. Semen ini digunakan sebagai bahan restorasi berupa tumpatan estetik pada gigi anterior, bahan liner dan basis. ${ }^{1}$

Semen ionomer kaca konvensional mempunyai beberapa keuntungan antara lain melepaskan fluorida untuk menghambat karies, dan tahan terhadap asam. Kekurangan semen ionomer kaca konvensional antara lain ketahanan yang rendah terhadap abrasi. ${ }^{2}$

Kefir adalah susu fermentasi yang memiliki rasa, warna dan konsistensi yang menyerupai yogurt, serta memiliki aroma khas yeasty (seperti tape). Kefir merupakan minuman kesehatan bergizi tinggi yang mengandung asam laktat, asam amino esensial, mineral, fosfor, magnesium kalsium, biotin, serta gula susu (laktosa) yang relatif rendah dibandingkan susu murni. Kefir juga dipercaya oleh sebagian masyarakat dapat menyembuhkan beberapa penyakit metabolisme seperti diabetes, asma, dan jenis tumor tertentu. ${ }^{3}$

Kefir diperoleh melalui proses pasteurisasi susu, kemudian difermentasi dengan bibit kefir. Bibit kefir terdiri atas butiran seukuran biji gandum berwarna putih, lembut, dan kenyal serta mengandung kumpulan bakteri, antara lain Streptococcus sp., Saccharomyces lactis., Lactobacilli sp., dan beberapa jamur non-patogen. Bakteri probiotik yang terkandung dalam kefir berperan menghasilkan asam laktat yang dapat menurunkan $\mathrm{pH}$ kefir menjadi asam, yaitu antara $3,4-4,6^{3}$

Asam laktat diketahui dapat menyebabkan terjadinya demineralisasi pada email gigi. Adanya reaksi terhadap hidroksiapatit, menyebabkan larutnya kalsium gigi, serta berkurangnya fosfor dan fluor dari email gigi yang dapat memudahkan terjadinya karies gigi. ${ }^{4}$

Penggunaan kefir sebagai minuman kesehatan dalam jangka waktu yang lama tentunya akan berpengaruh terhadap keadaan gigi dan bahan restorasi di dalam rongga mulut. Suatu bahan restorasi, termasuk semen ionomer kaca konvensional, yang berada dalam rongga mulut akan kontak langsung dengan cairan yang berada dalam rongga mulut. Cairan dalam rongga mulut dapat berupa saliva maupun minuman yang dikonsumsi, misalnya kefir yang bersifat asam.

Menurut O'Brien, ${ }^{2}$ semen ionomer kaca konvensional bersifat tahan terhadap asam. Demikian halnya dengan Powers ${ }^{5}$ yang menyatakan nilai kelarutannya terhadap asam laktat rendah dibanding semen berbahan dasar air lainnya. Sedangkan menurut van Noort $^{6}$ untuk jangka panjang semen ionomer kaca konvensional dapat terlarut akibat asam dan abrasi. Ketahanan suatu bahan terhadap abrasi dapat diketahui dengan menguji kekerasan permukaannya.

Berdasarkan sifat semen ionomer kaca konvensional yang mempunyai ketahanan abrasi rendah, serta adanya beberapa pendapat mengenai ketahanannya terhadap asam maka perlu diketahui apakah ada perubahan kekerasan permukaan semen ionomer kaca konvensional setelah perendaman dalam kefir.

Lama perendaman semen ionomer kaca konvensional dalam kefir antara lain ditentukan berdasarkan waktu terjadinya penyerapan awal dari minuman ringan, yaitu 3 menit. ${ }^{7}$ Aturan pakai kefir dalam sehari sebanyak 2 kali, sesuai aturan pabrik. Lama perendaman semen ionomer kaca konvensional pada penelitian ini adalah 6 menit, 18 jam, 36 jam dan 108 jam yang diasumsikan sama dengan penggunaan selama 1 hari, 6 bulan, 1 tahun, dan 3 tahun.

Tujuan penelitian ini adalah untuk mengetahui adanya perubahan kekerasan permukaan pada semen ionomer kaca konvensional setelah perendaman dalam kefir. 


\section{BAHAN DAN METODE}

Rancangan penelitian menggunakan post test only control group design. Penelitian ini dilakukan di Laboratorium Material Kedokteran Gigi Fakultas Kedokteran Gigi Universitas Airlangga dan Laboratorium Zat Padat Fisika Fakultas MIPA ITS Surabaya. Bahan yang digunakan adalah akuades (Durafarma Jaya, Indonesia), minuman kefir (Kefir, Indonesia), semen ionomer kaca konvensional konvesional Fuji II (GC Gold Label Universal Restorative, Japan, varnish (GC Fuji Varnish, Japan). Alat yang digunakan adalah cetakan sampel dengan diameter dalam $5 \mathrm{~mm}$ dan tinggi $3 \mathrm{~mm}$ berjumlah 54 buah, $^{8}$ anak timbangan seberat $1 \mathrm{~kg}$, botol kaca bertutup, celluloid strip, chip blower, cotton bud, gelas beker, gelas ukur, glass slab tebal, glass slab tipis, humidor, inkubator (Mitra Jaya, Indonesia), kertas amplas tahan air no.1000, kertas tissue, Micro Vickers Hardness tester (Future Tech Fm-7, Japan), paper pad dan spatula plastik, pengukur waktu, pinset, $\mathrm{pH}$ meter, pisau model.

Pembuatan sampel yaitu cetakan sampel diletakkan di atas glass slab yang telah diberi alas celluloid strip. Semen ionomer kaca konvensional yang terdiri dari bubuk dan cairan, diaduk dengan spatula plastik di atas paper pad dengan perbandingan 1 sendok takar : 1 tetes selama 30 detik (aturan pabrik), kemudian dimasukkan ke dalam cetakan sampel sampai penuh dan ditutup dengan celluloid strip. Di atas celluloid strip diletakkan glass slab tipis, kemudian diberi beban anak timbangan $1 \mathrm{~kg}$ sampai final setting, yaitu selama 5 menit 30 detik (sesuai petunjuk pabrik). Prosedur ini dilakukan sama pada setiap kelompok sampel. Setelah mencapai final setting, sampel dikeluarkan dari cetakan. Kelebihan sampel dirapikan menggunakan pisau model, kemudian seluruh permukaan dari sampel diulas dengan varnish satu lapis dengan menggunakan cotton bud yang selanjutnya dikeringkan dengan chip blower ${ }^{7}$ selama 30 detik dengan jarak dari sampel sejauh $10 \mathrm{~cm}$, kemudian tunggu selama 15 menit (aturan pabrik). Seluruh sampel disimpan dalam gelas beker yang berisi akuades steril kemudian diletakkan di dalam inkubator dengan suhu $37^{0} \mathrm{C}$ selama 24 jam. Setelah 24 jam, untuk menghilangkan varnish yang menempel pada permukaan sampel, maka seluruh permukaanya dihaluskan menggunakan kertas amplas tahan air no. 1000 di bawah air yang mengalir.?

Sampel dikelompokkan menjadi 6 kelompok. Kelompok 1 dan 5 direndam dalam cairan akuades steril (kelompok kontrol), masing-masing selama 6 menit dan 108 jam. Sampel kelompok 2, 3, 4, dan 6 direndam dalam kefir, masing-masing selama 6 menit, 18 jam, 36 jam dan 108 jam. Sampel direndam dengan posisi digantung dalam botol kaca bertutup sesuai dengan kelompoknya. ${ }^{7}$ Masing-masing botol berisi bahan perendam sebanyak $150 \mathrm{ml}$, agar sampel dapat terendam seluruhnya dalam bahan perendaman. Setelah direndam selama waktu yang telah ditentukan, sampel diangkat dari bahan perendaman. Sampel yang direndam dalam kefir, dicuci terlebih dahulu dengan akuades steril untuk menghilangkan sisa bahan rendam kefir. Selanjutnya keseluruhan sampel diletakkan ke dalam humidor hingga tiba saatnya untuk diukur. Sampel siap dilakukan uji kekerasan permukaan.

Sampel dikeluarkan dari humidor dan dikeringkan dengan kertas tissue untuk dilakukan pengukuran kekerasan permukaan. Bagian permukaan atas sampel yang akan diukur kekerasan permukaannya ditandai dengan spidol di tiga tempat. Pengukuran kekerasan permukaan sampel menggunakan alat Micro Vickers Hardness Tester dengan beban 500 gram. Sampel diletakkan di tengah landasan uji Micro Vickers 
Hardness Tester. Selanjutnya lensa okuler difokuskan dengan cara memutar pegangan searah jarum jam. Setelah pada lensa okuler terlihat gambar dalam keadaan fokus, ganti lensa dengan diamond penetrator. Alat diaktifkan sehingga ujung dari diamond penetrator menekan sampel dan secara otomatis diamond penetrator segera naik kembali (dalam waktu 6 detik), meninggalkan identasi pada permukaan sampel. Bentukan identasi diamati melalui lensa mikroskop dengan pembesaran 400 kali, sehingga tampak bentukan belah ketupat. Panjang diagonal diukur dengan menempatkan 2 tanda garis yang terlihat melalui lensa okuler atau pada layar monitor pada kedua ujung bentukan diagonal tersebut. Selanjutnya, tombol baca ditekan, akan muncul data nilai kekerasan permukaan dalam satuan Vickers Hardness Number. Setiap sampel dilakukan pengukuran kekerasan permukaan pada 3 tempat yang berbeda dan hasilnya dirataratakan.

Hasil pengukuran ditabulasi dan dianalisis secara statistik menggunakan one way ANOVA untuk menguji antar kelompok sampel terhadap kekerasan permukaan semen ionomer kaca konvensional. Selanjutnya untuk mengetahui perbedaan yang ada di antara kelompok sampel maka dilakukan uji least significant difference (LSD) pada taraf kemaknaan 5\%.

\section{HASIL}

Dari penelitian yang telah dilakukan, diperoleh nilai rerata kekerasan permukaan semen ionomer kaca konvensional pada masing-masing perlakuan. Data tersebut kemudian ditabulasikan dan dilakukan analisis statistik. Data yang diperoleh dari pengukuran kekerasan permukaan semen ionomer kaca konvensional setelah direndam dalam akuades dan kefir dapat dilihat pada tabel 1 .

Pada tabel 1 tampak nilai rerata kekerasan permukaan semen ionomer kaca konvensional setelah direndam dalam kefir dengan waktu perendaman yang semakin lama yaitu dari 6 menit, 18 jam, 36 jam, dan 108 jam, menunjukkan penurunan yang lebih besar dibandingkan dengan yang direndam dalam akuades sebagai kontrol. Untuk memperjelas kedudukan nilai kekerasan permukaan masing-masing perlakuan dan kontrol dapat dilihat pada grafik 1 .

Tabel 1. Nilai rerata dan simpang baku kekerasan permukaan semen ionomer kaca konvensional pada masing-masing kelompok (VHN).

\begin{tabular}{cll}
\hline Kelompok & N & $\bar{x} \pm$ SD \\
\hline I & 9 & $38,3633 \pm 0,38187$ \\
II & 9 & $31,0256 \pm 0,47810$ \\
III & 9 & $25,3011 \pm 0,56990$ \\
IV & 9 & $21,5589 \pm 0,37804$ \\
V & 9 & $34,8344 \pm 0,38400$ \\
VI & 9 & $11,7689 \pm 0,41664$ \\
\hline
\end{tabular}

\section{Keterangan:}

Kelompok I : Sampel direndam selama 6 menit dalam akuades sebagai kontrol

Kelompok II : Sampel direndam selama 6 menit dalam larutan kefir

Kelompok III : Sampel direndam selama 18 jam dalam larutan kefir

Kelompok IV : Sampel direndam selama 36 jam dalam larutan kefir

Kelompok V : Sampel direndam selama 108 jam dalam akuades sebagai kontrol

Kelompok VI : Sampel direndam selama 108 jam dalam larutan kefir

$\mathrm{N}$ : Jumlah sampel, $\bar{x}$ : Rerata, SD: Standar deviasi atau simpangan baku 


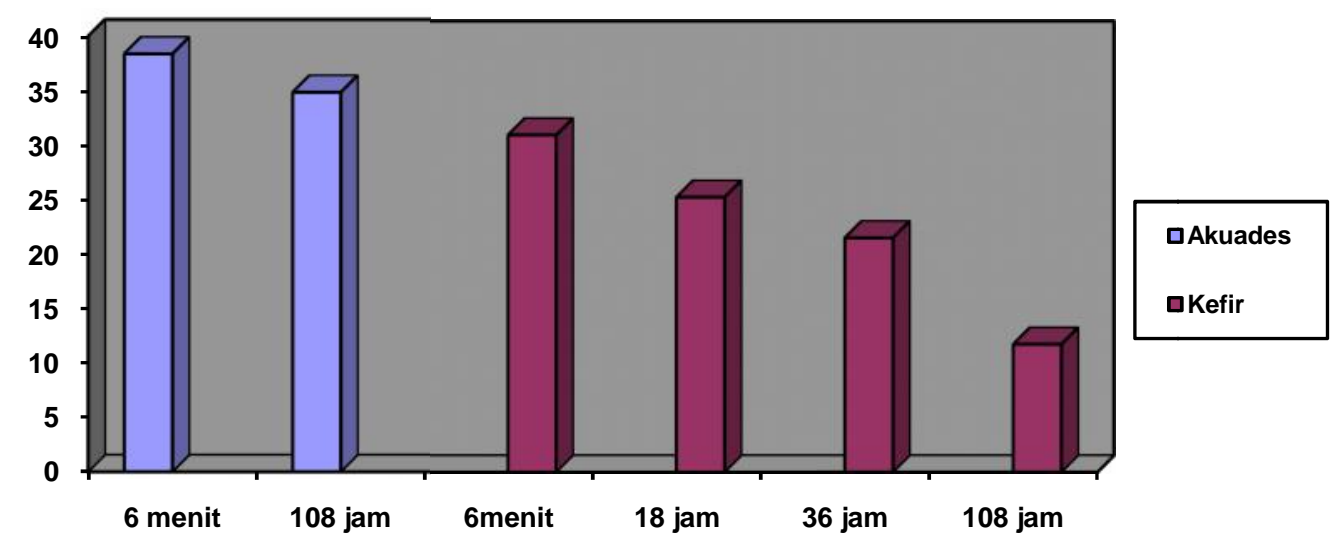

Grafik 1. Nilai kekerasan permukaan semen ionomer kaca konvensional setelah direndam dalam akuades maupun kefir
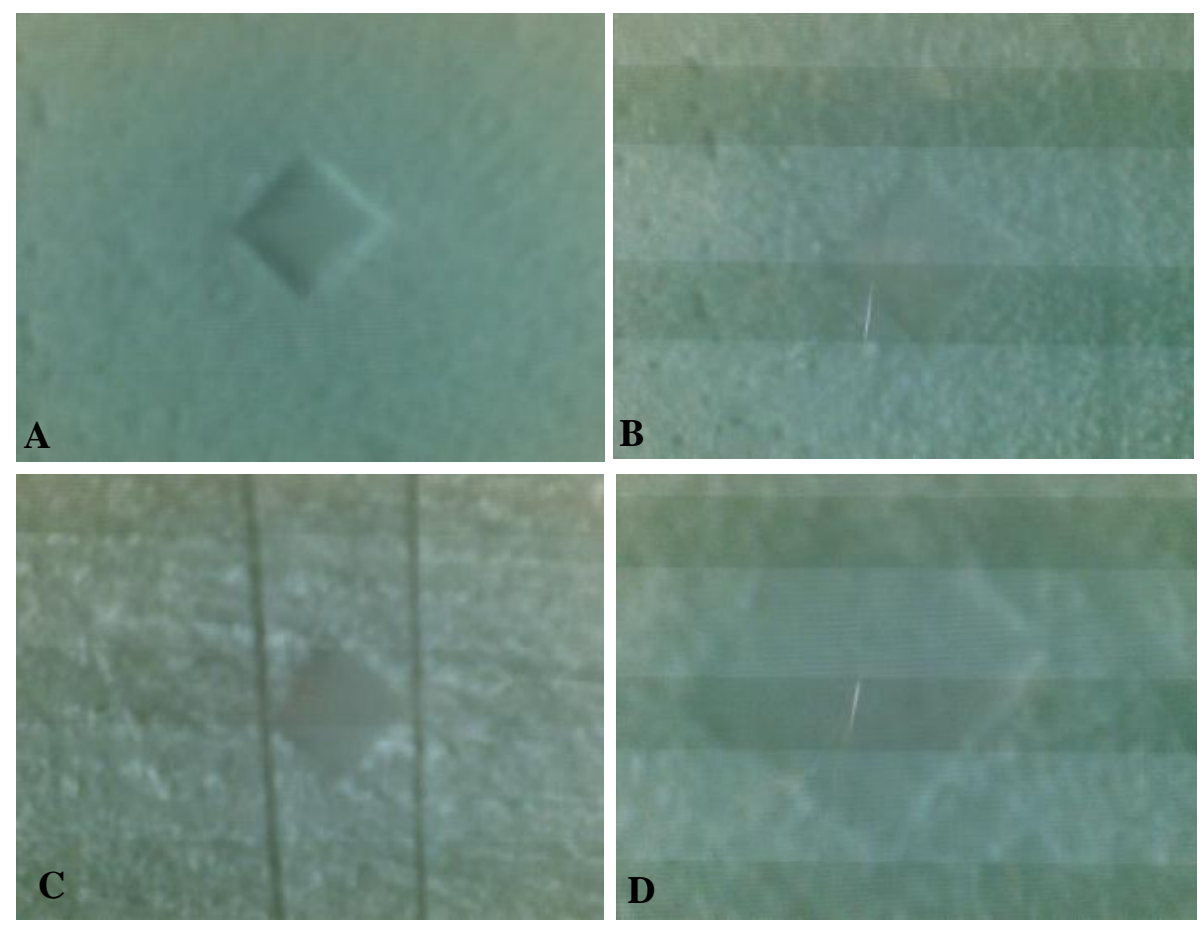

Gambar 1. Indentasi pada semen ionomer kaca konvensional. A. Hasil indentasi dari semen ionomer kaca konvensional direndam dalam akuades selama 6 menit. B. Hasil indentasi dari semen ionomer kaca konvensional direndam dalam akuades selama 108 jam. C. Hasil indentasi dari semen ionomer kaca konvensional direndam dalam kefir selama 6 menit. D. Hasil indentasi dari semen ionomer kaca konvensional direndam dalam kefir selama 108 jam.

Hasil pengamatan uji kekerasan permukaan semen ionomer kaca konvensional secara mikroskopik dengan pembesaran 400x dapat dilihat pada gambar 1.

Sebelum dilakukan uji parametrik untuk mengetahui kemaknaan perbedaan pada perlakuan dan kontrol, maka perlu dilakukan uji homogenitas pada masing-masing kelompok dan uji normalitas dengan uji Kolmogorov-Smirnov. Dari hasil uji diketahui $\mathrm{p}>0,05$ maka semua data homogen dan berdistribusi normal, sehingga memenuhi syarat untuk dilakukan uji parametrik menggunakan one way Anova dengan taraf kemaknaan $5 \%$. 
Tabel 2. Hasil Uji oneway Anova antar kelompok sampel terhadap kekerasan permukaan semen ionomer kaca konvensional

\begin{tabular}{cccccc}
\hline Sumber Variasi & Jumlah Kuadrat & dB & Rerata Kuadrat & F & p \\
\hline Antar Kelompok & 4239,599 & 5 & 847,920 & 4373,957 & 0,000 \\
Dalam Kelompok & 9,305 & 48 & 0,194 & & \\
\hline Total & 4248,904 & 53 & & & \\
\hline
\end{tabular}

Keterangan: $\mathrm{dB}=$ Derajat Bebas

$$
\begin{aligned}
& F=F \text { hitung } \\
& \mathrm{p}=\text { Probabilitas }
\end{aligned}
$$

Tabel 3. Hasil uji least significant difference pada tiap kelompok dari perendaman semen ionomer kaca konvensional dalam kefir dan akuades terhadap kekerasan permukaan (VHN)

\begin{tabular}{cllllll}
\hline Kelompok & I & II & III & IV & V & VI \\
\hline I & - & B & B & B & B & B \\
II & B & - & B & B & B & B \\
III & B & B & - & B & B & B \\
IV & B & B & B & - & B & B \\
V & B & B & B & B & - & B \\
VI & B & B & B & B & B & - \\
\hline
\end{tabular}

Keterangan: $\mathrm{B}=$ bermakna

Dari tabel 2, diketahui bahwa $\mathrm{p}<0,05$ yang berarti terdapat perbedaan bermakna antar kelompok. Selanjutnya untuk mengetahui perbedaan yang ada di antara kelompok sampel maka dilakukan uji least significant difference (LSD) pada taraf kemaknaan 5\%.

Dari tabel 3, tampak adanya perbedaan bermakna ditandai dengan adanya tanda "B". Perbedaan bermakna yang terjadi ini ditunjukkan juga dengan signifikasi berupa $\mathrm{p}<0,05$. Hal tersebut berarti perendaman semen ionomer kaca konvensional dalam kefir selama 6 menit, 18 jam, 36 jam, 108 jam, dan akuades selama 6 menit, dan 108 jam akan menurunkan kekerasan permukaan secara bermakna.

\section{PEMBAHASAN}

Telah dilakukan penelitian tentang pengaruh perendaman semen ionomer kaca konvensional dalam kefir terhadap kekerasan permukaan, kemudian dianalisis secara statistik menggunakan oneway Anova dan $L S D$ pada taraf kemaknaan $5 \%$. Hasilnya menunjukkan makin lama perendaman dalam kefir yaitu 6 menit, 18 jam, 36 jam, 108 jam dan akuades sebagai kontrol selama 6 menit, 108 jam, makin menurunkan nilai kekerasan permukaan semen ionomer kaca konvensional secara bermakna.

Semen ionomer kaca konvensional yang direndam dalam akuades selama 6 menit dan 108 jam mengalami penurunan kekerasan permukaan yang bermakna. Hal ini kemungkinan dapat terjadi oleh karena terdapat ion-ion yang terlepas dari semen ionomer kaca konvensional saat perlakuan perendaman dalam akuades. Ion-ion dari semen ionomer kaca konvensional yang paling banyak terlepas saat perlakuan perendaman dalam akuades adalah $\mathrm{Na}, \mathrm{Al}, \mathrm{Si}, \mathrm{P}, \mathrm{Ca} .{ }^{9}$ Air di sekitar semen ionomer kaca konvensional yang diserap akan mengganggu ikatan silang ion-ion logam, disebabkan ion-ion logam terutama ion $\mathrm{Ca}$ ikut terlarut dengan air. Ion $\mathrm{Ca}$ dan $\mathrm{Al}$ merupakan 
salah satu unsur penting di dalam proses pengerasan semen ionomer kaca konvensional karena berperan dalam membentuk ikatan silang terhadap molekul polimer. ${ }^{6}$ Terlepasnya ion-ion inilah yang akan menyebabkan kekerasan permukaan semen ionomer kaca konvensional menurun.

Semen ionomer kaca konvensional yang direndam dalam kefir selama 6 menit, 18 jam, 36 jam, dan 108 jam juga mengalami penurunan kekerasan permukaan yang bermakna. Asam yang terdapat dalam kefir adalah asam laktat yang merupakan salah satu asam kuat. Derajat keasaman $(\mathrm{pH})$ yang kuat dari asam laktat yaitu 3,6 dapat melarutkan kalsium dalam jumlah yang besar sehingga terbentuk kalsium laktat. Ion-ion yang paling banyak terlepas saat perlakuan perendaman dalam larutan asam laktat adalah $\mathrm{Na}$, $\mathrm{Al}, \mathrm{Ca}, \mathrm{Si}, \mathrm{P}$. Kadar kehilangan ion-ion ini akan jauh lebih besar jumlahnya pada perendaman dalam asam laktat dibandingkan pada akuades. ${ }^{9}$ Hal inilah yang menyebabkan terjadinya erosi pada permukaan semen ionomer kaca konvensional sehingga berdampak pula pada penurunan kekerasan permukaan yang cukup besar dari semen ionomer kaca konvensional.

Perendaman semen ionomer kaca konvensional dalam akuades maupun kefir mengakibatkan penurunan kekerasan permukaan secara bermakna, tetapi penurunan kekerasan permukaan semen ionomer kaca konvensional yang direndam dalam kefir jauh lebih besar dibandingkan dengan perendaman dalam akuades. Pelepasan ion florida pada perendaman semen ionomer kaca konvensional dalam akuades bekisar $70-75 \%$ sedangkan perendaman semen ionomer kaca konvensional dalam asam laktat yaitu dengan pelepasan ion fluorida yang hanya 4 $\%$. Pelepasan ion aluminium yang sangat tinggi dalam perendaman asam laktat dalam bentuk ikatan komplek aluminofluoro $\left(\mathrm{AlF}_{2}^{-}\right.$dan $\left.\mathrm{AlF}_{2}{ }^{+}\right){ }^{10}$ Hal ini kemungkinan juga berpengaruh terhadap salah satu sifat semen ionomer kaca konvensional sebagai bahan restorasi yang dapat melepaskan ion fluorida yang berperan sebagai antikariogenik.

\section{SIMPULAN}

Berdasarkan hasil penelitian, maka dapat disimpulkan bahwa terdapat penurunan kekerasan permukaan semen ionomer kaca konvensional setelah perendaman dalan akuades maupun kefir. Perendaman semen ionomer kaca konvensional dalam kefir menyebabkan penurunan kekerasan permukaan lebih besar dibanding dalam akuades. Makin lama perendaman semen ionomer kaca konvensional dalam akuades maupun kefir makin menurunkan kekerasan permukaan semen ionomer kaca konvensional.

\section{SARAN}

Menyikapi hasil penelitian ini, perlu dilakukan penelitian lebih lanjut tentang perubahan sifat fisik semen ionomer kaca konvensional setelah perendaman kefir.

\section{DAFTAR PUSTAKA}

1. Anusavice KJ. Philips science of dental material. $10^{\text {th }}$ Ed. St. Louis: WB Saunders Company; 2003. p. 47-9, 449-60.

2. O'Brien WJ. Dental materials and their selection. $3^{\text {rd }}$ Ed. Ontario: Quintessence Publishing Co, Inc; 2002. p. 146-9.

3. Pangkalan I. Health secret of kefir. Jakarta: PT Elex Media Komputindo; 2008. p. 54-5, 82-3.

4. Powers JM, Sakaguchi RL. Craig's restorative dental materials. $12^{\text {th }}$ Ed. St. Louis: Mosby Elsevier; 2006. p. 484-6.

5. Panjaitan Y. Pengaruh metabolisme plak gigi terhadap demineralisasi enamel. 2008. Available from: www.library.usu.ac.id. Accessed: Januari 1, 2009. 
6. Van Noort. Introduction to dental materials. $3^{\text {rd }}$ Ed. China: Mosby Elsevier; 2007. p. 12740.

7. Ratri AH. Kekerasan permukaan bahan semen ionomer kaca konvensional dan modifikasi resin setelah perendaman dalam minuman cola. [Skripsi]. Surabaya: Fakultas Kedokteran Gigi Universitas Airlangga; 2008. p. 2, 16-27, 36.

8. Asti M, Irmawati. Kekerasan permukaan semen ionomer kaca konvensional tipe II akibat lamanya penyimpanan. 2005. Available from: www.journal.unair.ac.id. Accessed on: Januari 14, 2009.

9. Czarnecka B, Limanowska-Shawand $\mathrm{H}$, Nicholson JW. Bufering and ion-release by a glass ionomer cement under near-neutral and acidic conditions. Biomater 2002; 23: 2783-8.

10. Czarneka B, John W, Nicholson. Ion release by resin-modified glass-ionomer cements into water and lactic acid solutions. J Dent 2006; 34: 539-43. 